confirming Maiden Castle's position as a classic reference in British prehistory. Of these, one was a crudely shaped chalk idol of the Mediterranean mother-goddess type, "an interesting and rare addition to the equipment of neolithic Britain"; and secondly a vast mound of later neolithic age, the largest of its kind as yet known, in one part of which was the skeleton of a young man with skull and long bones so hacked soon after death as to afford indubitable evidence of cannibalism.

\section{Expedition to Northern Syria}

Members of the joint expedition of the British Museum and the British School of Archæology in Iraq have left England for a fourth season of excava. tion on the archæological site of Tal Brak in northeast Syria. The expedition is in the charge of $\mathrm{Mr}$. M. E. L. Mallowan, field director. $\mathrm{He}$ is accompanied by Colonel A. H. Burn, Mr. G. H. Bell, who is the architect of the expedition, and $\mathrm{Mr}$. I. Threlfall. The excavations of previous seasons have shown that this site is especially remarkable for its evidence of early relations with Sumeria, and for its affinity with Hittite culture. This year the members of the expedition will continue the examination of a palace, which was laid out on an extensive scale under the dynasty of Sargon of Akkad about 2600 B.C. At the close of last season seven treasure chambers had been brought to light, but their examination had to be postponed as their condition was considered to be unsafe. Their investigation will now be resumed. The work of the expedition, however, will be directed more particularly to the remains of about the period 1500 B.c., when there was a considerable Hurrian population in the Khabur valley in close touch with both the cities on the Tigris to the east and with the Mediterranean coast to the west.

Twenty Years Progress in Science in the U.S.S.R.

THE twentieth anniversary of revolution is marked by the U.S.S.R. Academy of Sciences in the issue of special numbers of its periodical publications. The "Vestnik" of the Academy for October-November 1937 is a volume of 346 pages containing brief accounts of the work during the last twenty years of many, but not all, of the scientific institutes, museums and laboratories connected with the Academy. The number of such institutions has grown from 39 in 1917 to well over a hundred in 1937 , with more than 4,000 on the scientific and technical staff as against 212. The October part of "Priroda" (published in January 1938) contains a series of brief surveys of twenty years progress in different branches of sciences, namely, mathematics, astronomy, physics, aerodynamics, chemistry, geology, petrography, botany, physiology, zoology (separate articles on ornithology, mammology, ichthyology, entomology, ecology), palæontology, etc. Many of the articles have a broader basis and treat in a concise form the Russian contributions to the progress of science not only during the 'Stalin's era', as the period 1917-1937 is somewhat inexactly termed in the leading article, but also in the years before the revolution. Indeed, the work of such veterans of Russian science as the astronomer Struve, physicist Lebedev, the great Mendeléeff, physiologist Vvedensky, zoologists Menzbier and Sushkin, etc., is given fullest credit, and it is shown how their ideas have been developed by their numerous pupils and followers in later years.

\section{Official Tests of Composite Aircraft}

The combined seaplane Mercury and flying boat Maia, designed by Major Mayo and built by Messrs. Short Bros. of Rochester, mentioned in Nature of February 19, p. 321, passed the first properly observed separ ation trial on February 23. The actual operation was photographed with a cine-camera from another flying boat flying parallel with it, and knowing the exposure times, accurate measurements of the rate and angles of separation can be made. Subsequent views on the film show that the parting was instantaneous and that the gap widened steadily enough to ensure safety under all reasonable air conditions. The test were not quite the most severe, as Mercury was not fully loaded with petrol, having only about half her capacity on board. This reduction of weight is necessary to allow a safo landing. Normally most of the fuel would be consumed during the flight, or in an emergency it can be jettisoned. During the take off, the control is entirely in the hands of the pilot of the lower component, the flying controls of the upper machine being locked by the same mechanism that attaches the two machines. When he wishes to separate, he informs the upper pilot by telephone, waits for an agreed number of seconds, and pulls a lever that releases both the upper machine and its controls. The lower flying boat is trimmed so that it automatically becomes nose heavy when released and dips away, while the upper seaplane, at its best climbing attitude, climbs rapidly. The separation took place at about 800 feet height, flying at 140 miles an hour. These figures could probably be increased considerably should bumpy conditions in the air demand it. It is understood that both pilots, Mr. Lankester Parker and Mr. H. I. Piper, considered the tests to be satisfactory.

\section{Alchemy in Scotland}

Is a lecture given on February 4 at Marischal College, Aberdeen, before the local sections of the Institute of Chemistry and the Society of Chemical Industry, Prof. John Read of the University of St. Andrews gave an account of alchemy in Scotland. James IV of Scotland appointed an Italian, John Damian, as his court alchemist, a laboratory being founded in Stirling Castle about 1500. Accounts of the Lord High Treasurer from 1501 until 1513 contain information about the costs of the materials used by Damian and his associates in their attempts to prepare the "quinta essentia", which ended when the King was killed at Flodden Field in 1513. Alexander Seton, who is said to have travelled from Scotland to the Continent in 1602 and to have performed a series of transmutations in various German towns, was tortured by the Elector of Saxony and was rescued by the Polish nobleman Michael Sendi- 